\title{
New Invasive Insects Associated with Oak Forests in Lebanon
}

\author{
Zinette Moussa $^{1}$, Elia Choueiri ${ }^{2}$ and Abdallah Hanna ${ }^{3}$ \\ (1) Entomology Laboratory, Department of Plant Protection, Lebanese Agricultural Research Institute, \\ Fanar, Lebanon, Email: zmousa@lari.gov.lb; (2) Department of Plant Protection, \\ Lebanese Agricultural Research Institute (LARI), Tal Amara, Lebanon; (3) Skaff Estate, Ammiq, Bekaa.
}

\begin{abstract}
Moussa, Z., E. Choueiri and A. Hanna. 2021. New Invasive Insects Associated with Oak Forests in Lebanon. Arab Journal of Plant Protection, 39(2): 164-172.

Oak forests (Fagaceae) are native in Lebanon and occupy the largest areas of approximately 40,000 ha. The most common species are Quercus calliprinos, $Q$. infectoria, $Q$. cerris var. pseudo cerris and $Q$. brantii. Due to climate change and human activities, oak forests have become more vulnerable to native and exotic invasive pests. A total of 26 insect species associated with oak trees were recently identified in Lebanon. The most dangerous insect pest is the gypsy moth Lymantria dispar (Lepidoptera), on Q. calliprinos and Q. Cerris. The oak leafminer Phyllonorycter libanotica (Lepidoptera) and the Eriophidae (Accari) are the most species recorded on Q. infectoria and Q. calliprinos followed by the giant mealybug Ceroputo pilosellae (Hemiptera) on $Q$. infectoria and $Q$. calliprinos and the oak moth Thaumetopoea sp. (Lepidoptera) on $Q$. calliprinos and Q. Cerris. Eight new species were recorded for the first time in Lebanon on oak and are listed in this paper. Five species of Cinipidae (Hymenoptera): Andricus caputmedusae, A. cecconi, A. sternlichti, Plagiotrochus quercusilicis and Neuroterus quercusbaccarum, one species of Scolytidae, Xylosandrus compactus (Coleoptera), one species of Kermesidae Kermes echinatus (Hemiptera) and one species of Diaspididae, Koroneaspis aegilopos (Hemiptera).

Keywords: Lebanon, oak, forest decline, invasive species, outbreak
\end{abstract}

\section{Introduction}

Lebanon is located at the eastern edge of the Mediterranean covering an area of $10,452 \mathrm{~km}^{2}$. The country climate is typically Mediterranean characterized by humid to subhumid in winter and semi-arid in summer with major precipitation falling between December and March with snow in mountains. Forests are very particular in their diversity across the country. According to the Ministry of Environment (MoE) and the United Nations Environmental Programme MoE/UNEP (2015), the Lebanese forests constitute $13.4 \%$ of the national territory. The highest concentrations are located in Mount Lebanon (37\%) and North Lebanon (30\%), followed by South Lebanon (9\%) and Nabatieh (6\%) (FAO, 2010). Oak (Quercus spp) constitutes the major abundant forests with $52.42 \%$, followed by pine (Pinus spp) (14.91\%) and Juniper (8.74\%), while fir, cedar and cypress forests are much less abundant and are distributed in patches occupying $1.76 \%, 0.83 \%$ and 0.155 , respectively (FAO, 2005; MoE, 2012).

Oak forests (Fagaceae) are native in Lebanon and occupy approximately 40,000 ha. They are found at altitudes between 500 and 1800 meters (AFDC, 2007; MoE, 2012) mainly in the western slopes of the Mount Lebanon chain. On the eastern slopes of the chain, they extend discontinuously on low altitudes between Yammouneh and Hermel and on the slopes of Jabal Barouk-Niha. Only few oak stands persist on the western slopes of the Anti-Lebanon chain, mainly at Baalbeck, Rachaya and Hasbaya districts and in the south at Jabal Amel (METAP, 1995). According to MoA/FAO (2005) and Stephan et al. (2016), four endemic species of Quercus are dominants in Lebanon:
1) The Calliprine oak, Quercus calliprinos Webb, is the most common species growing between 500 and $1500 \mathrm{~m}$, usually associated with Pinus pinea and P. Brutia below $1000 \mathrm{~m}$ and with $Q$. infectoria between 1000 to $1500 \mathrm{~m}$.

2) The Aleppo oak, Q. infectoria Olivier, is the second dominant species standing between 200 and $1700 \mathrm{~m}$ and it is found accompanying $Q$. calliprinos and Pinus brutia.

3) The hairy/iron oak Quercus cerris var. pseudo cerris L. comes in the third place. It constitutes the most important pure stand at 1600 meters of altitude in the northern part of the Mount Lebanon in Qamou'a or Karm chbat forest associated with Quercus infectoria and Abies cilicica in mixed coniferous-broadleaved forest.

4) The Brant's oak Quercus brantii Lindl. is found in the southern part of Mount Lebanon and Mount Hermon between 1400 and $1800 \mathrm{~m}$ above sea level.

Other native minor species found are: The Lebanon oak $Q$. libani G. Olivier, the Cedar oak $Q$. cedrorum Ktschy, the Tabor oak $Q$. ithaburensis ungeri Decne., the Pubescent oak $Q$. pubescens Willd and the Kotschy oak Q. kotschyana $\mathrm{O}$. Schwarz (MoA/FAO 2005).

In Lebanon, some oak forests are maintained as natural reserves in Arz el Shouf Natural Reserve, Horsh Ehden Natural Reserve, Bentael Natural Reserve, Aammiq and Jabal Moussa (MoA/FAO, 2005). Outside of those natural reserves, oak forests like the other forests in Lebanon, are subject to various pressures making trees more vulnerable to pest and diseases as well as to invasive species causing decline of the forests and losses in natural resources. Insects associated with oak forests have been studied for a long time in Lebanon and they are mostly foliage feeders and 
woodborers belonging to the orders Lepidoptera and Coleoptera. The most common defoliating species are: Lymantria dispar (Linnaeus) (Demolin \& Nemer, 1999; Talhouk, 1950), Eriogaster phillipsi Bart. (Talhouk, 1969), Thaumetopea sp. (Demolin \& Nemer (1999) and Phyllonorycter libanotica (Deschka) (Deschka, 1972). Németh et al. (2019) reported height species of woodborers in the family of Cerambycidae on oak trees in Lebanon: Phymatodes testaceus (Linnaeus), Phymatodes lividus (Rossi), Phymatodes rufipes syriacus (Pic), Ropalopus ledereri wittmeri Demelt, Chlorophorus yachovi Sama, Hesperophanes sericeus (Fabricius), Purpuricenus dalmatinus Sturm and Niphona picticornis Mulsant. Ghahari et al. (2015) reported six buprestid beetles (Buprestidae) on oak in Lebanon: Agrilus cuprescens chrysoderes Abeille de Perrin, A. derasofasciatus Lacordaire, Acmaeodera flavolineata Laporte \& Gory, Anthaxia kiesenwetteri Marseul, Coraebus fasciatus (Villers) and Melanophila cuspidata (Klug). Gall wasps (Cynipidae) are considered minor pests on quercus. Two species are native to Lebanon: Cynips quercus (Fourcroy) and Andricus coriarius (Hartig) (Challis et al., 2007; Shachar et al., 2018) and three species are alien: Andricus moreae (Graeffe), Aphelonyx persica Melika, Stone, Sadeghi \& Pujade-Villar. and Chilaspis israeli Sternlicht (Katılmış \& Kıyak, 2009; Shachar et al., 2018). The aim of this paper is to present a list of insect pests associated with oak trees in Lebanon and their geographic distribution with description of new species.

\section{Materials and Methods}

\section{Field Survey and Insects Collection}

This study presents an analysis of data on insects associated with oak trees collected by the Lebanese Agricultural Research Institute (LARI) over a period of 10 years. Samples of branches and twigs of oaks were collected by the Entomology Laboratory (LARI) at Fanar in collaboration with the Department of Plant Protection (LARI) in Tal Amara. Other samples were received from citizens and municipalities across the country. Gall, leafminer, and wood borer insects at immature stages were reared in the Entomology Laboratory till adult's emergence. After identification, insect's specimens and damaged host parts were documented. Collected data includes pest name, host tree species, the date and the location of infestation.

\section{Weather Data Analysis}

Weather data was collected from the Department of AgroMeteorology at LARI for the past 10 years. Data of annual mean temperature, annual minimum temperature and precipitation from 5 meteorology stations were used in this study to cover all the regions of collected samples located in both the coastal and in the inland areas as follow: Douris Meteo Station that covers Baalbek region; Hasbaya Meteo Station that covers both Hasbaya and Rashaya regions; Ammiq Meteo station that covers West Bekaa and Shouf; Fanar Meteo Station that covers Metn and Keserwan regions; Kfar-shakhna Meteo Station that covers Jbeil and Batroun regions.

\section{Results}

A total of 26 insect species belonging to 15 families were identified on branches and leaves of four native oak tree species in Lebanon (Table 1), and they are as follows: Cynipidae (7); Diaspididae (6); Bupristidae (1); Eriophyidae (1); Gracillariidae (1); Coccidea (1); Thaumetopoeidae (1); Scolytidae (1); Kermesidae (1); Erebidae (1); Scarabidae (1); Noctuidae (1); Tortricidae (1); Cossidae (1), Aphididae (1). Specimens belonging to the family Tortricidae are larvae and are still being reared in the Entomology Laboratory for the purpose of identification. Among the insects identified in this study, eight species represent a new record for Lebanon. The following is a summary of the information gathered for the identified mites and insects:

Acari, Eriophyidae: The Eriophydae mite is very common on oak especially on $Q$. calliprinos (Figure 1- A \& B). It was recorded from low to high level of infestation in: Bentael IV 2013; Hasbaya XI 2016; Baalbek III 2018; Baalbek IV 2018; Baalbek IV 2019; Rachaya IV 2019; Kfifan V 2019; Fanar III 2020; Abrine IV 2020.

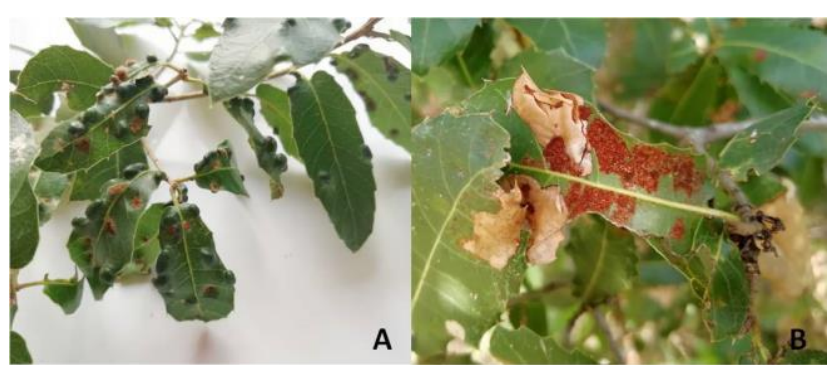

Figure 1. Eriophidae mites on leaves: (A) Galls on upper side; (B) Depression with rusty erineum at lower side.

Lepidoptera, Erebidae: The gypsy moth Lymantria dispar (Linnaeus) is one of the most dangerous and destructive pest on broadleaved trees in Lebanon. An outbreak occurred in Ammiq and Ain Zhalta VI 2019 causing a complete defoliation of $Q$. calliprinos, $Q$. infectoria and $Q$. brantii in the area (Figure 2- A). Both regions are connected together and are part of the Shouf Biosphere Reserve.

Lepidoptera, Thaumetopoeidae: The oak moth Thaumetopea sp. is another dangerous and destructive pest on broadleaved trees in Lebanon (Figure 2- B). The pest was recorded with high infestation on $Q$. calliprinos and $Q$. Cerris in Ammiq III 2018.

Lepidoptera, Gracillariidae: The oak leafminer Phyllonorycter libanotica (Deschka) is the most common pest infested $Q$. infectoria, $Q$. calliprinos and other oak species during the last 3 years in all the growing areas of the host species (Figure 2- C \& D). Recorded in: Abrine VI 2016; Baalbek III 2018; Baalbek IV 2018; Deir Ahmar IV 2018; Mazraat Dleil IV 2018; Smar Jbeil IV 2018; Ammiq VI 2018; Qab Elias VI 2018; Biyada VII 2018; Hasbaya XI 2018; Rachaya el Foukhar XI 2018; Ain Zhalta VI 2019; Dahr Ahmar IV 2019; Baalbek IV 2019; Rachaya IV 2019; 
Kfifan V 2019; Ajaltoun XI 2019; Abrine IV 2020; Kfir IV 2020.

Lepidoptera, Tortricidae: Leaf rollers belonging to the genus Choristoneura were spotted feeding on new growth leaves and catkins of Q. calliprinos in Abrine V 2020 (Figure 2- E \& F).

Lepidoptera, Noctuidae: Caterpillar of the small quaker, Orthosia cruda (Denis \& Schffermuller) was spotted feeding on the fresh leaves of $Q$. calliprinos. Recorded in: Abrine V 2020 .

Lepidoptera, Cossidae: Larva of the leopard moth Zeuzera pyrina (Linnaeus) was detected in the branch of $Q$. calliprinos in: Abrine VIII 2012.

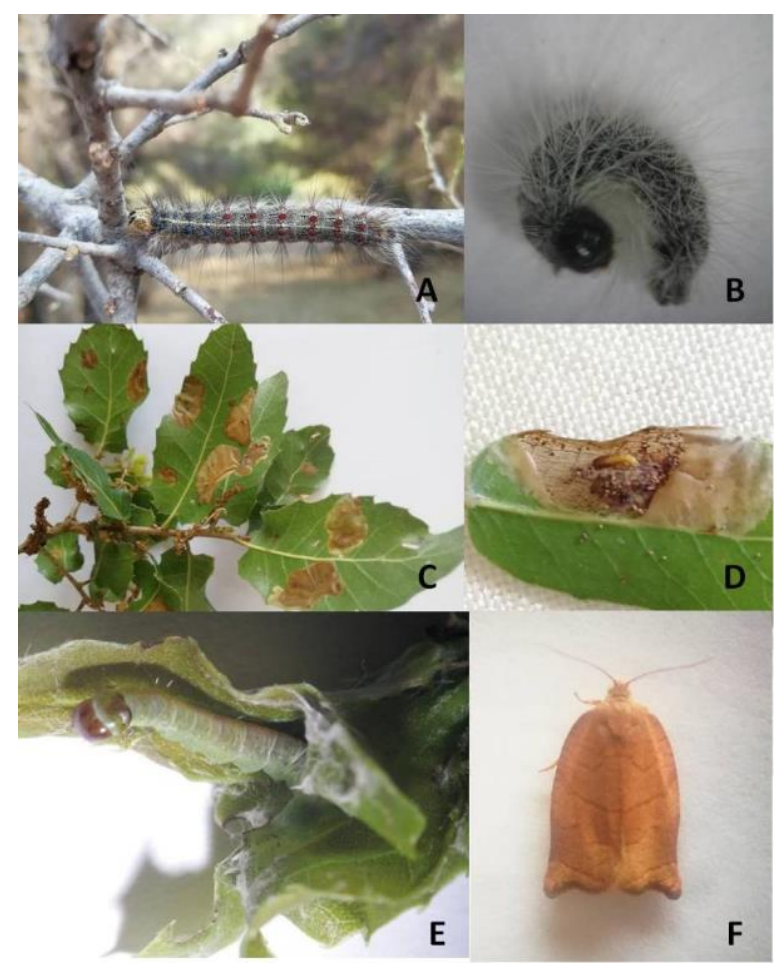

Figure 2. Leaf feeding moths: (A) The gypsy moth Lymantria dispar; (B) The oak moth Thaumetopea sp.; (C \& D) The damage caused by the oak leafminer Phyllonorycter libanotica; (E \& F) Larva and adult of Choristoneura sp.

Coleoptera, Buprestidae: The rose stem borer Agrilus cuprescens chrysoderes (Abeille de Perrin) (Figure 3- A \& B) was recorded with high infestation on $Q$. calliprinos in Baalbek IV 2013 and Jaj III 2020.

Coleoptera, Scolytidae: The black twig borer Xylosandrus compactus (Eichhoff) was identified for the first time in Lebanon on Q. calliprinos in Fanar XI 2017 and later in Shouf XI 2019 and Beirut VII 2020 (Figure 3- C \& D). Morphologically, $X$. compactus is very similar to $X$. germanus (Blandford). Nevertheless, it can be distinguished from the latter by the presence of flat setolae rows on both the striae and the interstriae of the elytral slope which is present and only weakly convex on the interstriae in $X$. germanus (Pennacchio \& Francardi, 2012).

Coleoptera, Scarabidae: Larvae of the common cockchafer Melolontha melolontha (Linnaeus) were found feeding on the roots of oak trees, recorded in: Misti Rechmaya II 2018.

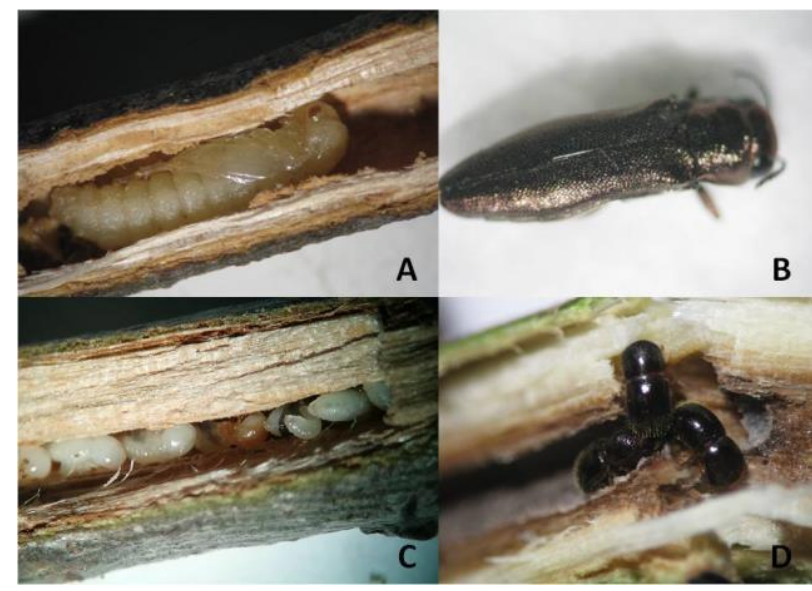

Figure 3. Stem borer: (A \& B) Pupae and adult of the rose stem borer Agrilus chrysoderes; (C \& D) Immature stages and adults of the black twig borer Xylosandrus compactus recorded as new species on Oak in Lebanon.

Hymenoptera, Cinipidae: Seven species of gall inducing wasps were reported on oak of which six were collected from $Q$. infectoria and one from $Q$. calliprinos. Five species were identified new to Lebanon (Figure 4, A to H) using the key to galls described by Shachar et al. (2018) as follows: 1Andricus caputmedusae (Hartig) recorded in: Shouf IX 2017; Hed VII 2018; 2- Andricus cecconi (Kieffer) recorded in : Bazbina IX 2018; 3- Andricus sternlichti (Bellido, Pujade-Villar \& Melika) recorded in: Bazbina IX 2018 4Plagiotrochus quercusilicis (Fabricius) recorded on $Q$. calliprinos in: Batroun V 2011; Ajaltoun VII 2017; Ammiq VI 2018; Abrine IV 2020; 5- Neuroterus quercusbaccarum (Linnaeus) recorded in: Bsharri VI 2019 and Shouf XI 2019 on leaves; Abrine IV 2020 on catkins (inflorescence of male flowers). The two other species are native in Lebanon: Cynips quercus (Fourcroy) recorded in Bekfaya IX 2017 and Andricus coriarius (Hartig) recorded in Bentaal IV 2017.

Hemiptera, Kermesidae: The scale Kermes echinatus (Balachowsky) was reported for the first time in Lebanon on Q. ilex in Hasbaya XI 2016 (Figure 5- A \& B). The females were post productive and the identification was done on the first instar nymphs according to Spodek \& Ben-Dov (2014).

Hemiptera, Coccidea: The giant mealybug Ceroputo pilosellae (Šulc) was recorded with high infestation during 2018 (Figure 5-C \& D) in: Baalbek III 2018; Ain Zabdi IV 2018; Deir Ahmar IV 2018; Mazraat Tleil IV 2018. The identification was done according to Williams et al. (2011). 


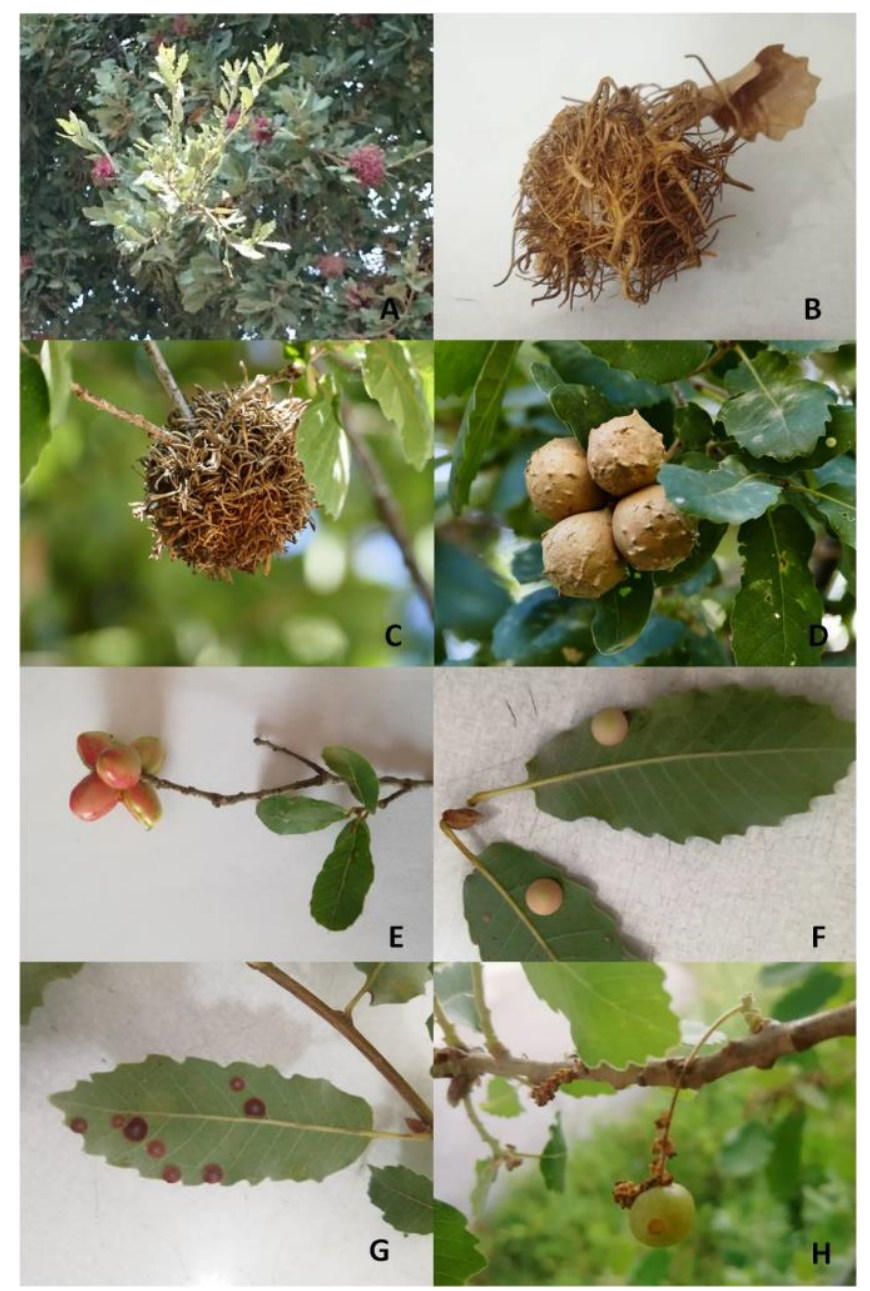

Figure 4. Galls caused by Cynipidae wasp recorded as new species on oak in Lebanon: (A) Galls of Andricus caputmedusae; (B) Mature gall of A. caputmedusae; (C) Mature gall of A. cecconi; (D) Mature gall of A. sternlichti; (E) Galls of Plagiotrochus quercusilicis; (F \& G) Gall form A and B of Neuroterus quercusbaccarum on leaves; (H) Gall form $\mathrm{C}$ of $N$. quercusbaccarum on catkins.

Hemiptera, Diaspididae: Six armored scales were reported on Quercus sp. with low population of which one is revealed new to Lebanon. In total, two species were identified by the Laboratory of Entomology (LARI), one species was identified by Hany Abdul Nour and labelled by (*) and three species were found in the old insect collection at LARI (Abdul-Nour \& Moussa, 2006). They are: 1- Aonidiella aurantii (Maskell): Baalbek IV 2019; 2- Aspidiotus nerii Bouché: Rabieh XI 1966; 3- Chionaspis lepineyi Balachowsky: Fanar III 1965; 4- Diaspidiotus viticola (Leonardi): Kfarzebiane VII 1967; 5- Gonaspidiotus minimus (Leonardi)*: Raachine VI 1983; Maad II 2006; 6- A new species Koroneaspis aegilopos was identified as described by Balachowsky (1954), it was found between thecolony of K. echinatus in Hasbaya XI 2016 (Figure 5- E \& F).

Hemiptera, Aphididae: One species of aphid belonging to the genus Myzocallis sp. was recorded in: Daraoun V 2014;
Mazraat Tleil VII 2018; Jdabra VI 2019. The specimens were nymphs which made the identification of the species difficult.

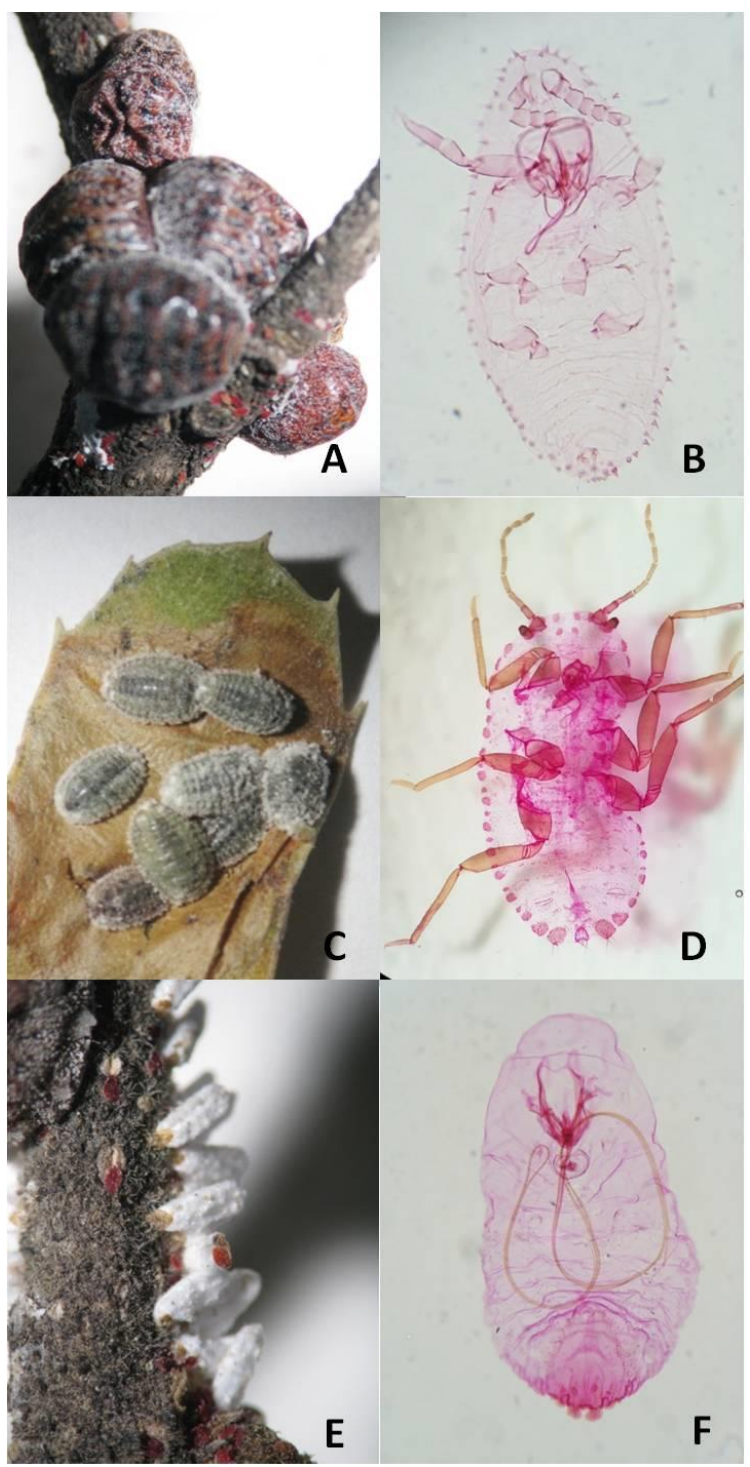

Figure 5. Oak scales: (A \& B) Post-productive female of Kermes echinatus recorded as new species on $Q$. ilex in Lebanon and microscope slide of first instar nymph; (C \& D) The Giant mealybug Ceroputo pilosellae and microscope slide of adult female; (E \& F) Immature males of Koroneaspis echinatus recorded as new species on $Q$. calliprinos in Lebanon and microscope slide of adult female.

\section{Discussion}

Based on this study, it is clear that we have 3 serious pests affecting oak in Lebanon: the gypsy moth Lymantria dispar, the oak moth Thaumetopea sp. causing defoliation and the oak leafminer Phyllonorycter libanotica causing dessication of leaves. The most infested oak species were Quercus calliprinos and Quercus infectoria. Another dangerous defoliating insect also reported on oak in Lebanon was Eriogaster phillipsi (Lepidoptera: Lasiocampidae) (Talhouk, 1969). 
Table 1. Distribution of oak pests and the number of infested sites in the different Lebanese Districts. New country records are denoted by an asterisk (*).

\begin{tabular}{|c|c|c|c|c|c|c|c|c|c|c|}
\hline Pest & $\begin{array}{l}\text { West } \\
\text { Bekaa }\end{array}$ & Baalbek & Rachaya & Hasbaya & Jbeil & Batroun & Shouf & Keserwan & Metn & Akkar \\
\hline \multicolumn{11}{|l|}{ Eriophyidae } \\
\hline Aceria sp. & & 3 & 1 & 1 & 1 & 2 & & & 1 & \\
\hline \multicolumn{11}{|l|}{ Lepidoptera } \\
\hline Lymantria dispar & 1 & & & & & & 1 & & & \\
\hline Thaumetopea processionea & 1 & & & & & & & & & \\
\hline Phyllonorycter libanotica & 2 & 7 & 2 & 2 & & 3 & 1 & 1 & & \\
\hline Choristoneura sp. & & & & & & 1 & & & & \\
\hline Orthosia cruda & & & & & & 1 & & & & \\
\hline Zeuzera pyrina & & & & & & 1 & & & & \\
\hline \multicolumn{11}{|l|}{ Coleoptera } \\
\hline Agrilus chrysoderes & & 1 & & & 1 & & & & & \\
\hline Xylosandrus compactus* & & & & & & & 1 & & 1 & \\
\hline Melolanta melolenta & & & & & & & 1 & & & \\
\hline \multicolumn{11}{|l|}{ Hymenoptera } \\
\hline Andricus coriarius & & & & & 1 & & & & & \\
\hline Andricus caputmedusae* & & & & & & & 1 & & & 1 \\
\hline Andricus sternlichti* & & & & & & & & & & 1 \\
\hline Andricus cecconi* & & & & & & & & & & 1 \\
\hline $\begin{array}{l}\text { Plagiotrochus } \\
\text { quercusilicis* }\end{array}$ & 1 & & & & & 2 & & 1 & & \\
\hline $\begin{array}{l}\text { Neuroterus } \\
\text { quercusbaccarum* }\end{array}$ & & & & & & 2 & 1 & & & \\
\hline Cynips quercus & & & & & & & & & 1 & \\
\hline \multicolumn{11}{|l|}{ Hemiptera } \\
\hline Kermes echinatus* & & & & 1 & & & & & & \\
\hline Ceroputo pilosellae & 1 & 3 & & & & & & & & \\
\hline Aonidiella aurantii & & 1 & & & & & & & & \\
\hline Aspidiotus nerii & & & & & & & & & 1 & \\
\hline Chionaspis lepineyi & & & & & & & & & 1 & \\
\hline Diaspidiotus viticola & & & & & & & & 1 & & \\
\hline Gonaspidiotus minimus & & & & & 2 & & & & & \\
\hline Koroneaspis aegilopos* & & & & 1 & & & & & & \\
\hline Myzocallis sp. & & 1 & & & & 1 & & 1 & & \\
\hline
\end{tabular}

Phyllonorycter libanotica was the most frequent pest recorded on oak during the past three years. This species is native to the country and it appears well established in the geographic distribution of Quercus species. The most damage observed with high level of infestation was from 7 sites in Baalbek district, followed by 3 sites in Batroun district, 2 sites in each of West Bekaa, Rachaya and Hasbaya districts, respectively (Table 1). Most of the samples were received in April where the damage was caused by the generation of the past fall. No parasitoids had emerged from these samples in the laboratory.

The oak moth Thaumetopea sp. was reported once by Demolin \& Nemer (1999) in 1998 on Q. calliprinos at Jabal el Barouk and Jabal Moussa as new species very close to the European oak moth $T$. processionea (Linnaeus). According to Demolin \& Nemer (1999), the main difference between the two species lies in the behavior of the pupae, where the pupation of the Lebanese moth takes place in the soil near the infested trees and the pupation of the European moth occurs on the base of the trunks and on the branches. EFSA (2009) suggested that the records of T. processionea from the Near East may not be reliable and further taxonomic studies are required.
Lymantria dispar has been recorded in Lebanon since 1950 without causing significant defoliation (Talhouk, 1950). Later, in June 1998, two outbreaks were been reported on $Q$. infectoria and $Q$. calliprinos at Jabal Moussa and Tourza defoliating more than 200 ha (Demolin \& Nemer, 1999). Four natural enemies on L. dispar were identified that year: one predator Calosoma sp. (Carabidae) and three parasitoids are Blepharipa sp. (Trachinidae), Brachymeria intermedia (Chalcididae) and Ooencyrtus kuvanae (Encyrtidae) (Demolin \& Nemer, 1999). However, in 2019, three species of parasitoids emerged in the Entomology Laboratory at LARI from larvae collected in the infested area at Ammiq and identified by the author as follows: one Chalcididae, Exorista larvarum (Trachinidae) and the other Brachymeria intermedia (Chalcididae). However, the level of parasitism was not studied in the infested site, but their presence in a natural reserve is considered as a biotic factor that could later reduce the population density to the innocuous phase.

More attention should be focused on the new invasive beetle, the black twig borer Xylosandrus compactus, since this species is an Ambrosia beetle and it is a highly polyphagous pest on more than 200 plant species according 
to EPPO (2017). The damage is caused by both the wood boring activity of the insect and the introduction of an associated fungus (EPPO, 2017). Even though the pathway of introduction is not well documented, it most probably has been introduced with trade of plant materials and then emerged adults have dispersed into nearby trees. The fact that the population of the beetle was recorded for the first time in 2017 at Fanar and later appeared in 2019 at $15.7 \mathrm{~km}$ further south inside the twigs of oak in Shouf, then in 2020 at Beirut suggest either the pest has spread and established in the country or has moved through infested plant material to another location. According to the literature, the main economic host is coffee (Coffea $s p$ ), but it could also attack pine (Pinus spp.), oak (Quercus sp.) fruit trees like sugar apple (Annona squamosa), lychee (Litchi chinensis), avocado (Persea Americana) and chinaberry (Melia azedarach), which are mostly imported plants. The spread of $X$. compactus represents a serious concern to the oak forests in Lebanon.

The $K$. echinatus population that was recorded for the first time on $Q$. ilex in Hasbaya, consisted mainly of post reproductive females and numerous first-instar nymphs. $Q$. ilex trees are rare in Lebanon and usually found in private gardens as ornamental trees. The high level of infestation by the kermes scales caused branch dieback and growth of sooty mold fungus due to the honeydew secretion. Few larvae of the predator Scutelista cyanea Motsch (Hymenoptera: Pteromalidae) were found inside adult females. This wasp is an important egg predator of the olive scale Saisseta oleae (Hemiptera, Coccidae) attacking olives, the main cultivated crop in the area.

The giant mealybug, Ceroputo pilosellae was reported on Euphorbiacea plants such as Puto pilosellae in North Lebanon (Ben-Dov \& Kaydan, 2008). This article represents the first record of $C$. pilosellae on oak in the country.

The Cynipidae was the most represented family in the oak insect checklist. Most gall wasps are not economically important. Galls induced by the species A. sternlichti (Figure 4-D) are well known in Lebanon and other countries of the Middle East since a long time for the production of tannin but never reported in the bibliography. The species was described only by Bellido et al. (2003) after revising the $A$. kollari group. However, Askew et al. (2003) mentioned 2 specimens of the parasitoid Eurytoma adleriae (Zerova) (Hymenoptera, Euritomidae) emerging from a sample of $A$. sternlichti collected from Lebanon.

The infestation level of the branches by the buprestid beetle Agrilus chrysoderes was very high in the region of Jaj causing dieback of the branches. Another important buprestid beetle attacking oak trees and reported in Lebanon is Coraebus fasciatus (Ghahari et al., 2015). In addition to the Buprestidae, Németh et al. (2019) identified 8 species of Cerambycidae emerged from oak trees: Phymatodes testaceus, P. lividus, P. rufipes syriacus, Ropalopus ledereri wittmeri Demelt, Chlorophorus yachovi Sama, Hesperophanes sericeus, Purpuricenus dalmatinus and Niphona picticornis. Rouault et al. (2006) noted that forest woodborers were positively influenced by the high temperatures through increasing their development rates and by the long period of drought which lower host tree resistance and increase their susceptibility to insect pests.
Other new species reported in this paper are restricted in specific regions with acceptable damage. However, some honeydew secreting insects like the giant mealybug $C$. pilosellae can play an important role in the honey production in the region of Baalbek and West Bekaa.

Pests and associated host plants are very influenced by the climate. White (1984) and Rouault et al. (2006) demonstrated that severe water stress after long drought decreases tree resistance to pest attacks and may affect the nutritional quality of plants by increasing the level of foliar nitrogen which may, in turn, stimulate insect feeding and increase damages. Battisti (2004) has studied the effect of climate change on the behavior of forest insects through adjusting their life cycles, increasing population and increasing consumption. The analysis of the climatic data in different regions showed that Lebanon is facing milder winter, hotter and drier summers and reduction in precipitation during the past decade which affect the ground water discharge and induce water stress to trees. The precipitation has declined (Figures $6 \& 7$ ) and the annual mean temperature has been slightly raised (Figure 8) and the droughts have become longer between 2013 and 2017. The later years showed the lowest level of precipitation in all the regions. This change in the climatic condition could interfere with the life cycle of the insects causing an exponential growth of the population and a high infestation. However, the prolonged drought from 2013 till 2017 was followed by abundant precipitation at the end of 2018 and through the year 2019 (Figures 6 \& 7) and have induced a high vegetative growth rate providing available food to new hatched larvae in spring. According to the Department of AgroMeteorology in Ammiq, the temperature did not fall below $3^{\circ} \mathrm{C}$ in winter 2018 with few cold days compared to the previous winters when temperatures have reached -9.6, -8.7 and $-17.3^{\circ} \mathrm{C}$ (Figure 9). The temperature which is considered as abiotic factor to arthropods has contributed to reduction in egg mortality in a winter followed by warm spring during the larval growth which is synchronized with leaf flush.

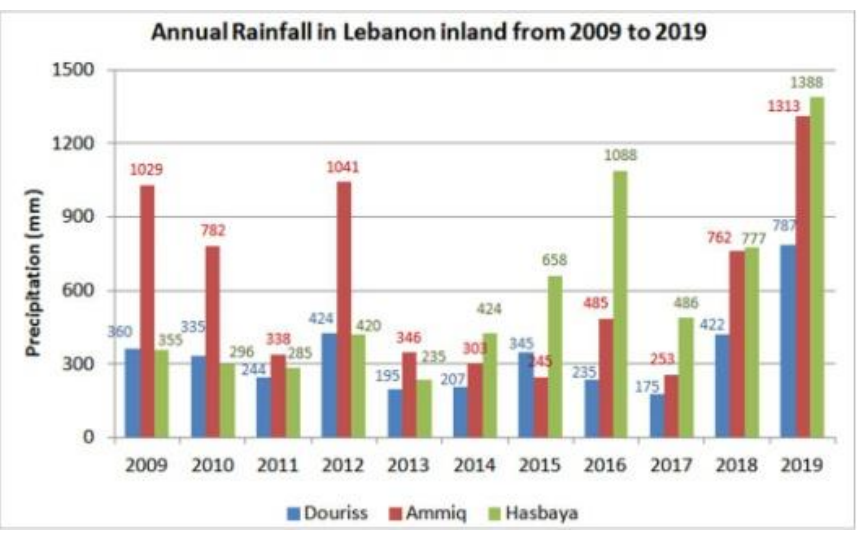

Figure 6. Variation in annual rainfall $(\mathrm{mm})$ in the inland area during the period 2009-2019. Source: Department of Irrigation and Agro-Meteorology (LARI). 


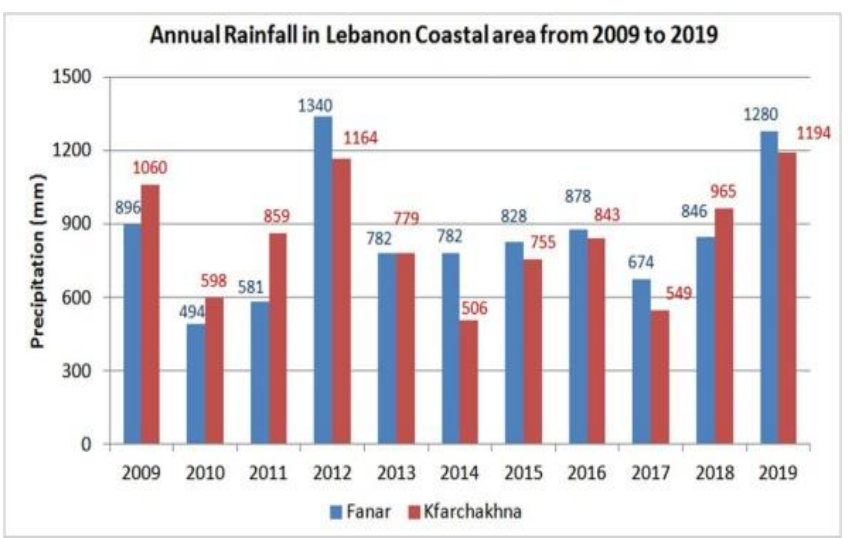

Figure 7. Variation in annual rainfall $(\mathrm{mm})$ in the coastal area during the period 2009-2019. Source: Department of Irrigation and Agro-Meteorology (LARI).

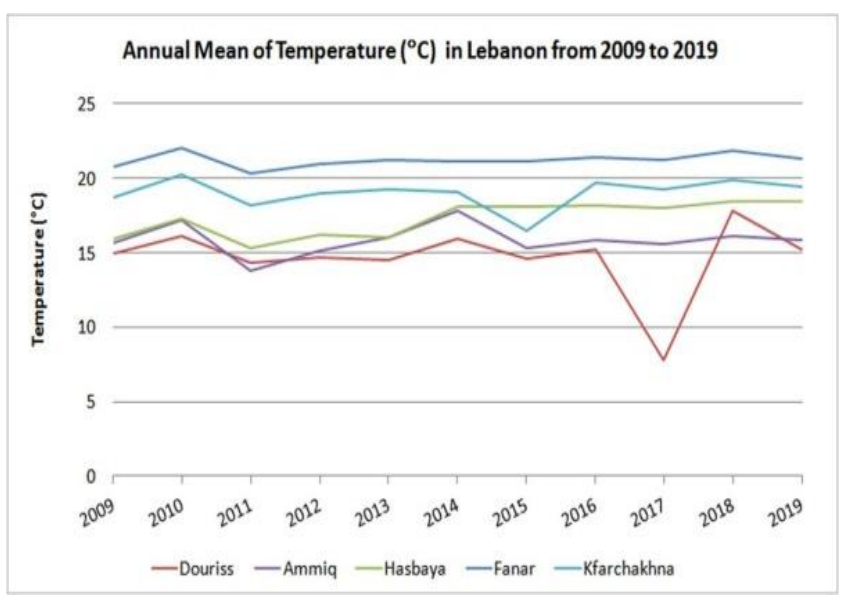

Figure 8. Variation in the annual mean of temperature $\left({ }^{\circ} \mathrm{C}\right)$ in different regions of Lebanon during the period 20092019. Source: Department of Irrigation and AgroMeteorology (LARI).

In addition, oak forests, like the other forests in Lebanon, suffer over the last century from fragmentation, fire and human practices such quarries, charcoal, fuel wood production and overgrazing putting forests under pressure (Mitri et al., 2015). The absence of a national forest management policy, the lack of human awareness towards bird hunting and the use of toxic insecticides that kill beneficial predators and parasites have contributed to the degradation of the Lebanese forests. Beside the threats from native pests, international trade of plant materials increases the risk of accidental introductions of invasive alien insects from infested countries through commodities that may contain different life-stages of alien pests. Introductions of such alien species could have severe economic and ecological consequences on our forests. The combination of both abiotic and biotic factors described above have contributed together in the increase of pest population and the decrease of host plant resistance making the oak forests in Lebanon more vulnerable to pest attack.

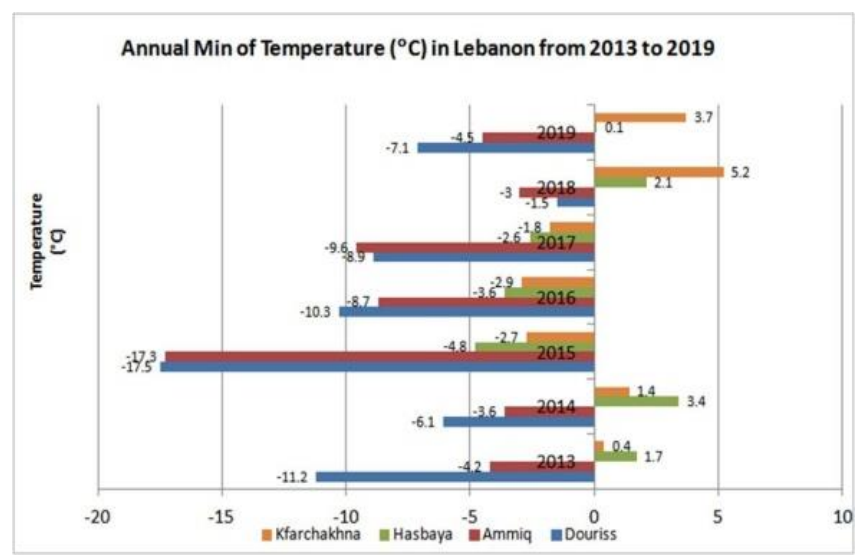

Figure 9. Variation in the Annual Minimum of Temperature $\left({ }^{\circ} \mathrm{C}\right)$ in different regions of Lebanon during the period 2013 - 2019. Source: Department of Irrigation and AgroMeteorology (LARI).

\section{Acknowledgements}

The authors are grateful to the Department of Irrigation and Agro-Meteorology at LARI for the weather data.

\section{الملخص}

موسى، زينات، إيليا الشويري وعبد الله حنا. 2021. حشرات جديدة غازية تصيب غابات السنديان والبلوط في لبنان. مجلة وقاية النبات العربية، 39(2): .172-164

تعد غابات السنديان في لبنان محلية وتحتل أكبر مساحة بين الغابات حيث تبلع حوالي 40000 هكتار. الأنواع الأكثر شيوعاً وانتشاراً هي البلوط

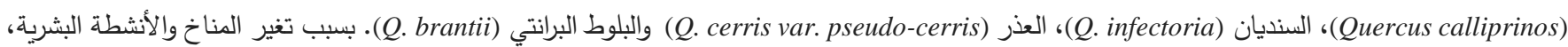
تدهورت غابات السنديان والبلوط في لبنان حتى أصبحت أكثر عرضة للآفات الحشرية المحلية والغازية. تم من خلال هذه الدراسة تحديد 26 نوعاً من الحشرات التي تصيب أشجار السنديان في لبنان. تعد الغراشة الغجرية Lepidoptera) Lymantria dispar) من أخطر الآفات على أشجار البلوط والعذر ـ أما حافرة أوراق السنديان (Lepidoptera) Phyllonorycter libanotica

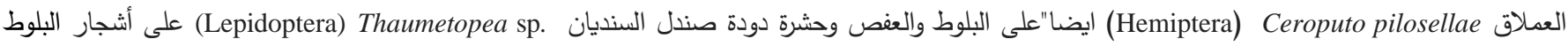
والعذر. سجلت 8 أنواع جديدة من الحشرات على السنديان في لبنان تمّ التطرق اليها في هذه النشرة كما يلي: 5 أنواع من دبابير الكرات المرارية 
‘(Hymenoptera: Cinipidae) Neuroterus quercusbaccarum و Plagiotrochus quercusilicis ‘A. sternlichti ،A. cecconi ‘Andricus caputmedusae

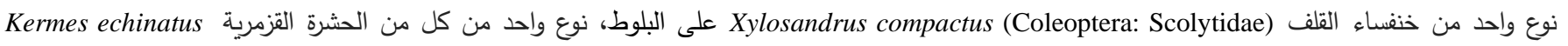
(Hemiptera: Diaspididae) Koroneaspis aegilopos والحشرة القشرية (Hemiptera: Kermesidae)

عنوان الباحثين: موسى، زينات، إيليا الشويري² وعبد الله حنا3. (1) مختبر الحشرات، قدم وقاية النبات، محطة الأبحاث العلمية الزراعية، الفنار، لبنان، البريد الإكتروني: zmousa@lari.gov.lb (2) قسم وقاية النبات، محطة الأبحاث العلمية الزراعية، تل عمارة، البقاع، لبنان؛ (3) مزرعة سكاف، عميق،

$$
\text { البقاع، لبنان. }
$$

\section{References}

Abdul-Nour, H. and Z. Moussa. 2006. Inventaire des Diaspididae du Liban (Hemiptera, Sternorrhyncha, Coccoidae). Bulletin de la Société entomologique de France, 111: 517-520.

AFDC. 2007. Association for Forests, Development and Conservation. State of Lebanon's Forests, Beirut. $128 p p$.

Askew, R.R., G. Melika, J. Pujade-Villar, K. Schonrogge, G.N. Stone and J.L. Nieves-Aldrey. 2003. Catalogue of parasitoids and inquilines in cynipid oak galls in the West Palaearctic Zootaxa, 3643: 001-133. https://doi.org/10.11646/zootaxa.3643.1.1

Balachowsky, A.S. 1954. Les cochenilles Paléarctiques de la tribu des Diaspidini. Memmoires Scientifiques de l'Institut Pasteur Paris, 450 pp.

Battisti, A. 2004. Forests and Climate Change - Lessons from Insects. iForest-Biogeosciences and Forestry, 1: $1-5$. https://doi.org/10.3832/ifor0210-0010001

Bellido, D., P. Ros-Farré, G. Melika and J. Pujade-Villar. 2003. Review of the asexual forms of the Andricus kollari species-group (Hymenoptera: Cynipidae, Cynipinae, Cynipini). Folia Entomologica Hungarica, 64: 197-248.

Ben-Dov, Y. and M.B. Kaydan. 2008. Puto pilosellae (Šulc), new synonymy and distribution records (Hem. Coccoidea, Putoidae). Bulletin de la Société Entomologique de France, 113: 285-286.

Challis, R.J., S. Mutun, J.L. Nieves-Aldrey, S. Preuss, A. Rokas, A. Aebi, E. Sadeghi, M. Tavakoli and G.N. Stone. 2007. Longitudinal range expansion and cryptic eastern species in the western Palaearctic oak gallwasp, Andricus coriarius. Molecular Ecology, 16: 21032114. https://doi.org/10.1111/j.1365-294X.2006.03210.x

Demolin, G. and N. Nemer. 1999. Defoliator insects of Quercus callyprinos Webb. and Quercus infectoria Oliv. in Lebanon. IOBC/wprs Bulletin, 22: 65-71.

Deschka, G. 1972. Lithocolletis (=Phyllonorycter) libanotica spec. nov. (Lep., Lithocolletidae). Entomologische Berichten, 32: 8-90.

EFSA. 2009. Evaluation of a pest risk analysis on Thaumetopoea processionea L., the oak processionary moth, prepared by the UK and extension of its scope to the EU territory. The EFSA Journal, 1195, 1-64.
EPPO. 2017. https://www.eppo.int/ACTIVITIES/ plant_quarantine/alert_list_insects/xylosandrus_comp actus

FA0. 2005. Global Forest Resources Assessment Country Report - Lebanon. FRA2005/059. Rome, FAO. 34 pp.

FAO. 2010. Global Forest Resources Assessment. Main report, FAO Forestry Paper No. 163, Rome.

Ghahari, H., M.G., Volkovitsh and C.L., Bellamy. 2015. An annotated catalogue of the Buprestidae of Iran (Coleoptera: Buprestoidea). Zootaxa, 3984: 001-141. https://doi.org/10.11646/zootaxa.3984.1.1

Katılmış, Y. and S. Kıyak. 2009. The oak gallwasp Aphelonyx persica: A new record from Turkey, with some new host records. Phytoparasitica, 37: 95-97. https://doi.org/10.1007/s12600-008-0006-3

METAP. 1995. Mediterranean Environmental Technical Assistance Program Lebanon: assessment of the state of the environment for the ministry of environment. Final report.

Mitri, G., M. Jazi and D.Mc. Wethy. 2015. Assessment of wildfire risk in Lebanon using Geographic Objectbased image analysis. Photogrammetric Engineering and Remote Sensing, 81: 499-506. https://doi.org/10.14358/PERS.81.6.499

MoA/FAO. 2005. National Forest and Tree Assessment and Inventory. TCP/LEB/2903 Project Document. 112 pp.

MoE. 2012. Biodiversity and Forests. Ministry of Environment of Lebanon. http://www.moe.gov.lb/Sectors/BiodiversityForests.aspx

MoE/UNEP. 2015. Fifth National Report of Lebanon to the Convention on Biological Diversity. 146 pp.

Németh, N., K. Székely, A. Kotán, A. Márkus, W. Yammine, C. Tanios and N. Nemer. 2019. Notes on longhorn beetles of Lebanon (Coleoptera: Cerambycidae). Folia Entomologica Hungarica, 80: 13-38. https://doi.org/10.17112/FoliaEntHung.2019.80.13

Pennacchio, F. and V. Francardi. 2012. Bioecological notes on Xylosandrus compactus (Eichhoff) (Coleoptera Curculionidae Scolytinae), a species recently recorded into Italy. Redia, 95: 67-77. 
Rouault, G., J.N. Candau, F. Lieutier, L.M. Nageleisen, J.C. Martin and N. Warzée. 2006. Effects of drought and heat on forest insect populations in relation to the 2003 drought in Western Europe. Annals of Forest Science, 63: 613-624. https://doi.org/10.1051/forest:2006044

Shachar, E., G. Melika, M. Inbar and N. Dorchin. 2018. The oak gall wasps of Israel (Hymenoptera, Cynipidae, Cynipini)-diversity, distribution and life history. Zootaxa, 4521: 451-498. https://doi.org/10.11646/zootaxa.4521.4.1

Spodek, M. and Y. Ben-Dov. 2014. A taxonomic revision of the Kermesidae (Hemiptera: Coccoidea) in Israel, with a description of a new species. Zootaxa, 3781: 001-099. https://doi.org/10.11646/zootaxa.3781.1.1.

Stephan, J., L. Chayban and F. Vessella. 2016. Abiotic factors affecting oaks distribution in Lebanon. Turkish Journal of Botany, 40: 595-609. https://doi.org/10.3906/bot-1601-24

Received: May 20, 2020; Accepted: April 8, 2021
Talhouk, A.S. 1950. A list of insects observed on economically important plants and plant products in Lebanon. Bulletin de la Societe Fouad 1er d'entomologie, 34: 133-141.

Talhouk, A.S. 1969. Insects and mites injuries to crops in Middle Eastern Countries. Monographien zur angewandten. Entomologie $N^{\circ} 21$ : Verlag Paul Parey, Hamburg and Berlin. 239 pp.

White, T. 1984. The abundance of invertebrate herbivores in relation to the availability of nitrogen in stressed food plants. Oecologia, 63: 90-105. https://doi.org/10.1007/BF00379790

Williams, D.J., P.J. Gullan, D.R. Miller, D. MatileFerrero and S.I. Han. 2011 A study of the scale insect genera Puto Signoret (Hemiptera: Sternorrhyncha: Coccoidea: Putoidae) and Ceroputo Šulc (Pseudococcidae) with a comparison to Phenacoccus Cockerell (Pseudococcidae). Zootaxa, 2802: 1-22. https://doi.org/10.11646/zootaxa.2802.1.1

تاريخ الاستلام: 2020/5/20؛ تاريخ الموافقة على النشر: 2021/4/8 